\title{
SOIL NEMATODES OF CONIFEROUS FORESTS IN THE FINNISH-RUSSIAN FRIENDSHIP NATURE RESERVE
}

\author{
Anna A. Sushchuk* ${ }^{\mathbb{D}}$, Elizaveta M. Matveeva ${ }^{\mathbb{C}}$ \\ Institute of Biology of Karelian Research Centre of RAS, Russia \\ *e-mail:anna_sushchuk@mail.ru
}

Received: 07.09.2020. Revised: 23.11.2020. Accepted: 16.12.2020.

\begin{abstract}
The article describes the communities of soil nematodes in pine (hereinafter-Pinus sylvestris) and spruce (hereinafter - Picea abies) forests in the Finnish-Russian Friendship Nature Reserve. It exemplifies typical northtaiga forests and combines Kostomuksha State Nature Reserve (Republic of Karelia, Russia) and Friendship Park, consisting of five Protected Areas in the adjacent area of Finland. Methods commonly applied in nematology were used to study the following parameters: taxonomic diversity, population density, biomass, eco-trophic structure of nematode communities, and ecological indices representative of the soil food web. In the coniferous forests, the soil nematode fauna was made up of 45 nematode genera belonging to 29 families, with the highest diversity demonstrated by bacterial feeders ( $42 \%$ of the total number of taxa detected). Coniferous forests in the Finnish territory featured a high number of taxa (29-33) and high values of the Shannon index $\left(\mathrm{H}^{\prime}\right)(3.4-3.8)$ as compared to their counterparts in the Kostomuksha State Nature Reserve (18-24 taxa and $\mathrm{H}^{\prime}=2.4-3.3$, respectively). A general trend for all the surveyed forests was a decrease in nematode abundance and biomass from the forest litter towards the mineral soil layer, which was more pronounced on the Finnish territory. A Principal Component Analysis of relative abundance of functional guilds of nematodes showed that forests of Eastern Finland had a more uniform nematode fauna among soil horizons. Analysis of the eco-trophic structure of nematode communities in soils under the coniferous forests revealed a high abundance of bacterial feeders, fungal feeders and nematodes associated with plants, while plant parasites were scarce or missing. In pine forests of both Russian and Finnish parts of the Friendship Nature Reserve, soil nematode communities were noted for a higher diversity and relative abundance of predators, while those in spruce forests had a higher abundance of fungal feeders than in pine forests. The regional features of the nematode fauna in the Kostomuksha State Nature Reserve were a low diversity and high dominance levels of taxa (high Simpson's index values), low maturity index $(\Sigma \mathrm{MI})$ and structure index (SI) of the nematode communities, possibly as a result of human impact or other local-scope adverse environmental factors. The forest nematode communities in the Finnish territory showed a higher diversity of the fauna and a lower dominance level of taxa (a more evenly structured nematode fauna). The Finnish forests harboured 16 specific taxa not encountered in the Russian territory and plant parasites of the family Trichodoridae, which were rare in Northwest Russia. In addition, the group of dominant taxa included Kstrategy nematodes sensitive to the environmental conditions. All this suggests that the conditions on the Finnish side are more favourable for soil nematodes. The ecological indices explored in the study (SI, EI) confirm that Finnish coniferous forests are stable habitats with complex, multicomponent soil food webs and undisturbed soil ecosystems. On the contrary, the indices for forests of the Kostomuksha Stare Nature Reserve betray a simplified and unstable food web associated with degraded soil ecosystems exposed to detrimental environmental impacts.
\end{abstract}

Key words: eco-trophic structure, ecological indices, population density, Protected Area, soil nematode community, taxonomic diversity

\section{Introduction}

The purpose of establishing the Finnish-Russian Friendship Nature Reserve in 1989 was to promote co-operation between Finland and the USSR within the fields of environmental protection, maintaining and studying the natural environment of the frontier zone, and monitoring the status of ecosystems. The Friendship Nature Reserve includes the Friendship Park on the Finnish side and Kostomuksha State Nature Reserve in the Kostomuksha district (Republic of Karelia, Russia). Initially, the tasks of the Kostomuksha State Nature Reserve, founded in 1983, included not only the conservation of pristine areas of northern taiga ecosystems, but also the neutralisation of the negative consequences of industrial activities of the Kostomuksha Mining and Processing Plant (MPP), a major source of air and soil pollution in the North of the Republic of Karelia. A majority of research in the region was associated with organised environmental monitoring of boreal forests in the MPP area, including the study of atmospheric precipitation, groundwater, soil, flora and fauna. Concerning pedobionts, the impact of emissions from the Kostomuksha MPP on soil nematodes in coniferous forest (Matveeva et al., 2008; Gruzdeva \& Sushchuk, 2009) and meadow (Laidinen et al., 2013) ecosystems was assessed. However, the nematode diversity and the status of nematode communities in the soils of intact forests in this area have not been studied previously.

Nematological studies in Finland were carried out, mainly, taking into account the impact of various types of environmental transformation on soil 
nematodes, including clear-cutting, landscape reclamation and other forestry practice (Huhta et al., 1967; Räty \& Huhta, 2003; Dighton et al., 2012), reindeer (Rangifer tarandus (Linnaeus, 1758)) grazing (Stark et al., 2000, 2008), and herbicide application in agroecosystems (Hagner et al., 2019). Publications describing the nematode abundance, biomass, fauna diversity and community structure in natural forests are less widely presented (Huhta \& Koskenniemi, 1975; Magnusson, 1982; Huhta et al., 1986, 2005). At the same time, much research on soil nematodes in Finland, including forest ecosystems, were carried out several decades ago with the analysis of various groups of soil invertebrates at the level of high taxonomic units.

The intensifying anthropogenic ecosystem transformation leads to constant reduction of natural habitats for living organisms. In this connection it is urgent to study the flora and fauna of undisturbed ecosystems in Protected Areas as potential etalon sites for monitoring the environment and identifying the distribution patterns of organisms. The Friendship Nature Reserve is an excellent example of successful co-operation of nature reserves operating across the Finnish-Russian border for studying and preserving all components of the natural environment and carrying out ecological monitoring in the adjacent area. Within the framework of this co-operation, we carried out nematological investigations in the coniferous forests. This study aims to contribute to a better knowledge of the nematode fauna in coniferous forests in the Finnish-Russian Friendship Nature Reserve, including taxonomic diversity, population density and community structure of soil nematodes in the protected and intact coniferous forests of the Kostomuksha State Nature Reserve and the border area of Finland.

\section{Material and Methods}

\section{Study area}

The study on the nematode diversity was conducted in coniferous forests in 2006-2007 (August) in the Kostomuksha State Nature Reserve (Republic of Karelia, Russia) (hereinafter - NR Kostomuksha) and in the adjacent area of Finland (Elimyussalo Nature Reserve, the largest Protected Area in Kainuu region, Kuhmo municipality, Eastern Finland). To study, we selected the four sampling sites, including one pine (hereinafter - Pinus sylvestris L.) and one spruce (hereinafter - Picea abies (L.) H.Karst.) forest site in each region (Fig. 1). The main characteristics of sampling sites established in Kostomuksha State Nature Reserve and Eastern Finland are presented in Table 1.

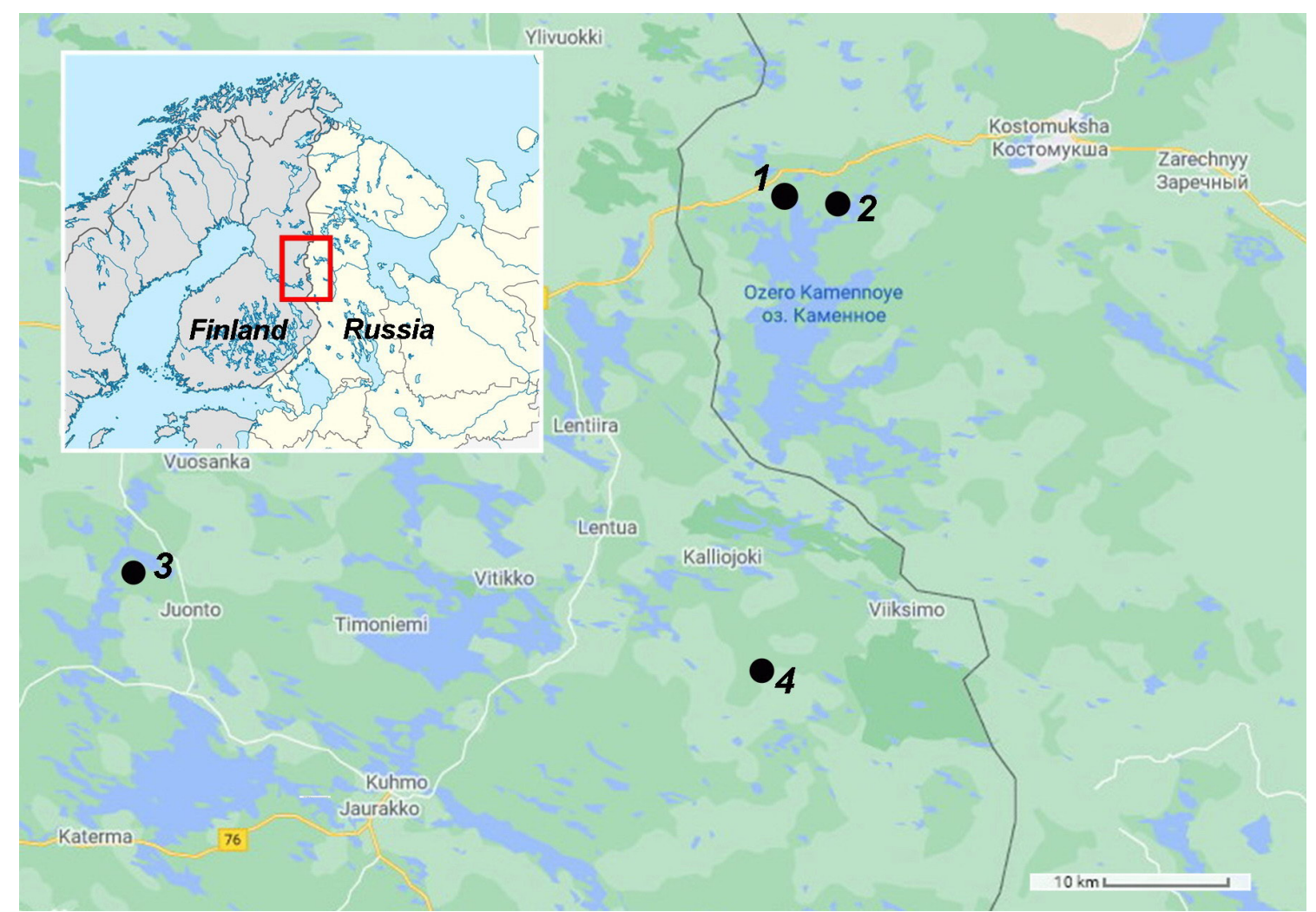

Fig. 1. Map of the study area in the Republic of Karelia (Russia) and Eastern Finland, illustrating four sampling sites. Designations: Site 1 - pine (Pinus sylvestris) forest in the Kostomuksha State Nature Reserve; Site 2 - spruce (Picea abies) forest in the Kostomuksha State Nature Reserve; Site 3 - pine (Pinus sylvestris) forest in the Kuhmo municipality, Kainuu region of Eastern Finland; Site 4 - spruce (Picea abies) forest in the Elimyussalo Nature Reserve, Eastern Finland. 
Table 1. Characteristics of the sampling sites in the study area

\begin{tabular}{|c|c|c|c|c|}
\hline \multirow{2}{*}{ Parameters } & \multicolumn{4}{|c|}{ Sites } \\
\hline & Site 1 & Site 2 & Site 3 & Site 4 \\
\hline Latitude N & $64.560938^{\circ} \mathrm{N}$ & $64.546215^{\circ} \mathrm{N}$ & $64.293145^{\circ} \mathrm{N}$ & $64.208052^{\circ} \mathrm{N}$ \\
\hline Longitude E & $30.156037^{\circ} \mathrm{E}$ & $30.244796^{\circ} \mathrm{E}$ & $29.071056^{\circ} \mathrm{E}$ & $30.160255^{\circ} \mathrm{E}$ \\
\hline Forest type & Bilberry-cowberry pine forest & Bilberry spruce forest & Rocky pine forest & True-moss spruce forest \\
\hline \multicolumn{5}{|c|}{ Plant species per forest layer } \\
\hline Canopy layer & $\begin{array}{c}\text { Pinus sylvestris L., Picea } \\
\text { abies (L.) H. Karst., Populus } \\
\text { tremula L. }\end{array}$ & $\begin{array}{c}\text { Picea abies (L.) H. Karst., } \\
\text { Pinus sylvestris L. }\end{array}$ & Pinus sylvestris $\mathrm{L}$. & Picea abies (L.) H. Karst. \\
\hline Understory & $\begin{array}{c}\text { Sorbus aucuparia L., Betula } \\
\text { pendula } \text { Roth, Juniperus com- } \\
\text { munis L. }\end{array}$ & $\begin{array}{l}\text { Juniperus communis L., } \\
\text { Sorbus aucuparia L. }\end{array}$ & $\begin{array}{l}\text { Betula pendula Roth, Picea } \\
\text { abies (L.) H. Karst., Junipe- } \\
\text { rus communis L. }\end{array}$ & - \\
\hline Field layer & $\begin{array}{l}\text { Vaccinium myrtillus L., Vac- } \\
\text { cinium vitis-idaea } \mathrm{L} .\end{array}$ & Vaccinium myrtillus L. & $\begin{array}{l}\text { Calluna vulgaris (L.) Hull, } \\
\text { Vaccinium vitis-idaea L., } \\
\text { Vaccinium myrtillus L. }\end{array}$ & $\begin{array}{l}\text { Vaccinium myrtillus L., } \\
\text { Carex sp. }\end{array}$ \\
\hline Moss-lichen cover & $\begin{array}{l}\text { Sphagnum sp., Polytrichum } \\
\text { commune Hedw. }\end{array}$ & - & $\begin{array}{l}\text { Pleurozium schreberi } \\
\text { (Willd. ex Brid.) Mitt., } \\
\text { Dicranum polysetum Sw. }\end{array}$ & $\begin{array}{l}\text { Sphagnum sp., Polytrichum } \\
\text { commune Hedw. }\end{array}$ \\
\hline \multicolumn{5}{|c|}{ Soil parameters } \\
\hline Soil type* & \multicolumn{2}{|c|}{ Carbi-Ferric Podzols } & Leptosols & Carbi-Gley Podzols sandy \\
\hline Soil $\mathrm{pH}_{\mathrm{KCl}}{ }^{*}$ & \multicolumn{2}{|c|}{ 3.0-3.5 (highly acidic soils) } & $\begin{array}{l}3.04 \text { (horizon } \mathrm{A} 0) \text {, } \\
4.80 \text { (horizon } \mathrm{A} 1 \mathrm{~B})\end{array}$ & $\begin{array}{l}.4 \text { (horizon A0), } \\
3.3 \text { (horizon A2) }\end{array}$ \\
\hline$\% \mathrm{C}^{*}$ & \multicolumn{2}{|c|}{32.9 (forest litter), 0.72 (horizon A2) } & $\begin{array}{l}51.08 \text { (horizon A0), } \\
8.73 \text { (horizon A1B) }\end{array}$ & $\begin{array}{c}44.9 \text { (horizon A0), } \\
0.3 \text { (horizon A2) }\end{array}$ \\
\hline$\% \mathrm{~N}^{*}$ & \multicolumn{2}{|c|}{2.0 (forest litter), 0.04 (horizon A2) } & $\begin{array}{l}0.94 \text { (horizon } \mathrm{A} 0 \text { ), } \\
0.56 \text { (A1B horizon) }\end{array}$ & $\begin{array}{l}1.33 \text { (horizon } \mathrm{A} 0 \text { ), } \\
0.06 \text { (A2 horizon) }\end{array}$ \\
\hline
\end{tabular}

Note: * - according to Fedorets et al. (2014); \% C - organic carbon, \% N - total nitrogen.

\section{Soil sampling and nematode extraction}

Soil samples were randomly taken from each of the four sites within a typical homogeneous plot of forest $(2 \times 2 \mathrm{~m})$ with a corer $(20 \mathrm{~mm}$ in diametre) separately at the depths of $0-5 \mathrm{~cm}$ (forest litter) and 5-10 cm (mineral layer). Nine soil samples were collected on site 2 and site 3 , and five to nine replicates on site 1 and site 4 . In total, 63 soil samples were collected. Each of them was placed in a zip-lock plastic bag, and transported within $48 \mathrm{~h}$ to the Laboratory of Animal and Plant Parasitology, Institute of Biology, Karelian Research Centre of RAS. In the laboratory, samples were stored at field moisture content at $4^{\circ} \mathrm{C}$ and within one week the soil samples were weighted and subjected to further analysis. Nematodes were extracted alive from the soil by modified Baermann funnel method for $48 \mathrm{~h}$. Then they were heat-killed and fixed using TAF (trietanolamin : formalin : water in ratio $2: 7: 91$ ) (van Bezooijen, 2006). The nematodes were placed on glycerol slide, and counted. At least 100 individuals from each sample were identified to genus level using a microscope at 400-600 magnification.

\section{Nematode analysis}

Names and order of nematode taxa are according to De Ley \& Blaxter (2004) and Abebe et al. (2006). To assess the status of nematode communities, the following parameters were used: taxonomic diversity (number of genera), Shannon index $\left(\mathrm{H}^{\prime}\right)$ of genera, Simpson domination index (Odum, 1975), density of nematode populations (individuals/100 $\mathrm{g}$ fresh soil), nematode biomass (mg/100 g soil), eco-trophic structure of nematode communities. Total biomass was calculated from mean biomass of genera using the web-based tool NINJA: Nematode Indicator Joint Analysis (Sieriebriennikov et al., 2014).

An eco-trophic grouping of nematodes was made according to Yeates et al. (1993a,b). Each taxon was assigned to one of six trophic groups, namely bacterial feeders (B), fungal feeders (F), omnivorous nematodes $(\mathrm{Om})$, predaceous nematodes $(\mathrm{Pr})$, plant parasites $(\mathrm{Pp})$, and nematodes associated with plants (Asp), which can feed on both the epidermal root cells and fungal hyphae, and they often called «root-fungal feeders». In addition, when analysing the fauna diversity, the trophic group of insect parasitic nematodes (IP) (dispersal/infective stages) was taken into account (Yeates et al., 1993a). However, this group was excluded from further analysis of soil nematode communities, because these species do not contribute to soil processes.

The maturity index ( $\Sigma \mathrm{MI})$ was calculated as a quantitative estimation of soil ecosystem status 
based on the composition and ratio of nematode taxa. Nematode species have various environmental features related to their morphology, biology, and ecology and are expressed in the values assigned to each taxon on the c-p Bongers scale (Bongers, 1990). Colonisers with the lowest value (cp 1) are resistant to adverse environmental conditions and have a high reproduction rate. Persisters are species with the highest value (cp 5), having characteristics opposite to colonisers (i.e. large size and low reproduction rate), and being sensitive to environmental factors.

Ferris et al. (2001) expanded the term of eco-trophic grouping with the concept «functional guild» of nematodes, which combined the feeding habits of taxa and c-p-classes reflecting the life strategies of nematodes (Bongers, 1990; Yeates et al., 1993a). Functional guilds are served as a base for calculation of ecological indices (EI, SI, CI - see below), characterising the soil food web. The enrichment index (EI) describes the enrichment of soil with organic matter. The structure index (SI) reflects an increase in the number of trophic linkages in an ecosystem, the degree of maturity of the soil food web, complexity, and stability of the environment. The channel index (CI) shows the dominant pathway of organic matter decomposition in soil ecosystem with the participation of bacteria or soil fungi (Ferris et al., 2001).

Statistical data processing was carried out using the Mann-Whitney U-test for a small number of replicates to compare the characteristics of nematode communities between coniferous forests of the Friendship Nature Reserve. Differences between groups obtained at level of $p<0.05$ were considered significant. Numerical data are presented as mean \pm standard error of the mean. A principal component analysis (PCA) was used to explore the ordination of sampling sites (forest biocenoses) on the base on soil nematode fauna composition and functional guilds. Calculations were performed using the PAST 1.68 (Hammer et al., 2001). The research was carried out using the facilities of the Equipment Sharing Centre of the Karelian Research Centre of RAS.

\section{Results}

\section{Taxonomic diversity}

Overall, 45 taxa of soil nematodes belonging to 29 families and 9 orders were found throughout the coniferous forests of the NR Kostomuksha and the border region of Eastern Finland. A total of 18, 24, 33, and 29 genera were recorded for Site 1, Site 2, Site 3, and Site 4, respectively (Table 2). Twelve taxa occurred in all habitat types, accounting for $\sim 27 \%$ of the total fauna. These were represented by bacterial feeders (Acrobeloides, Chiloplacus, Plectus, Prismatolaimus, Teratocephalus), fungal feeders (Aphelenchoides, Ditylenchus, Tylencholaimus), nematodes associated with plants (Coslenchus, Lelenchus, Malenchus), and one omnivore (Eudorylaimus) (Table 2).

Analysis of the soil nematode taxonomic diversity showed that in Finland coniferous forests are distinguished by a higher number of identified taxa (29-33 genera) and a higher Shannon index $\left(\mathrm{H}^{\prime}=3.4-3.8\right)$ than coniferous forests in NR Kostomuksha. The lowest number of nematode taxa was noted in the pine forests in the NR Kostomuksha (18 genera, $\mathrm{H}^{\prime}=2.4-2.8$ ) (Table 2, Table 3). The considerable increase in nematode fauna diversity of forests in the border zone of Eastern Finland was established due to specific species (16) harboured only in these biocenoses, while only six specific taxa were registered in the Russian territory. Among these taxa preferring a specific habitat or region, nematodes from three trophic groups (plant parasites, predators, omnivores) predominated. They have demands on environmental conditions or the presence of a host plant (Table 2).

The nematode families with the highest taxonomic diversity were Tylenchidae (7 genera), Cephalobidae (5 genera), and Plectidae ( 3 genera). Another four families included two taxa each. Twenty-two families had only one taxon (Table 2), indicating that taxonomically poor families make a significant contribution to the nematode fauna of the study area. Most of the taxa were bacterial feeders (19 genera). The second place was taken by plant parasites (7 taxa). In addition, the diversity of plant parasites changed depending on the soil horizon. So, as a rule, plant parasites tended to the lower mineral soil layer and were absent in the forest litter (Table 3). In terms of contribution to the total taxonomic diversity, the third place was shared by representatives of predators and nematodes associated with plants (6 taxa in each group). The fourth place was shared by fungal feeders and omnivores (3 taxa each). In addition, we identified the genus Steinernema, belonging to the group of invertebrate parasites with soil-dwelling larvae. 
Table 2. Mean relative abundance (\%) of nematode taxa in the soil of four coniferous forests in the Finnish-Russian Friendship Nature Reserve

\begin{tabular}{|c|c|c|c|c|c|c|c|c|c|}
\hline \multirow{3}{*}{ Taxa } & \multirow{3}{*}{$\begin{array}{l}\text { Functional } \\
\text { guilds of } \\
\text { nematodes }\end{array}$} & \multicolumn{4}{|c|}{ Kostomuksha State Nature Reserve } & \multicolumn{4}{|c|}{ Eastern Finland (Kuhmo and Elimyussalo) } \\
\hline & & \multicolumn{2}{|c|}{$\begin{array}{c}\text { Site } 1 \\
\text { (pine forest) }\end{array}$} & \multicolumn{2}{|c|}{$\begin{array}{c}\text { Site } 2 \\
\text { (spruce forest) }\end{array}$} & \multicolumn{2}{|c|}{$\begin{array}{c}\text { Site } 3 \\
\text { (pine forest) }\end{array}$} & \multicolumn{2}{|c|}{$\begin{array}{c}\text { Site } 4 \\
\text { (spruce forest) }\end{array}$} \\
\hline & & $0-5 \mathrm{~cm}$ & $5-10 \mathrm{~cm}$ & $0-5 \mathrm{~cm}$ & $5-10 \mathrm{~cm}$ & $0-5 \mathrm{~cm}$ & $5-10 \mathrm{~cm}$ & $0-5 \mathrm{~cm}$ & $5-10 \mathrm{~cm}$ \\
\hline \multicolumn{10}{|c|}{ Order Enoplida Filipjev, 1929} \\
\hline \multicolumn{10}{|c|}{ Family Alaimidae Micoletzky, 1922} \\
\hline Alaimus De Man, 1880 & $\mathrm{~B}_{4}$ & 0 & 0 & 0.7 & 0 & 0 & 2.3 & 0 & 0 \\
\hline \multicolumn{10}{|c|}{ Order Triplonchida Cobb, 1920} \\
\hline \multicolumn{10}{|c|}{ Family Trichodoridae Thorne, 1935} \\
\hline Trichodoridae sp. & $\mathrm{Pp}_{4}$ & 0 & 0 & 0 & 0 & 0 & 0 & 0 & 0.2 \\
\hline \multicolumn{10}{|c|}{ Family Prismatolaimidae Micoletzky, 1922} \\
\hline Prismatolaimus de Man, $1880^{*}$ & $\mathrm{~B}_{3}$ & 0 & 0.2 & 1.1 & 0.3 & 0 & 0.9 & 1.5 & 2.4 \\
\hline \multicolumn{10}{|c|}{ Family Tobrilidae Filipjev, 1918} \\
\hline Tobrilus Andrássy, 1959 & $\operatorname{Pr}_{3}$ & 0 & 0 & 0 & 0 & 0 & 0.4 & 0 & 0 \\
\hline \multicolumn{10}{|c|}{ Family Tripylidae de Man, 1876} \\
\hline Tripyla Bastian, 1865 & $\operatorname{Pr}_{3}$ & 0 & 0 & 0 & 0 & 0 & 0.3 & 0 & 0.2 \\
\hline Trischistoma Cobb, 1913 & $\operatorname{Pr}_{3}$ & 0.7 & 1.5 & 0 & 0 & 0.8 & 0 & 0 & 0 \\
\hline \multicolumn{10}{|c|}{ Order Dorylaimida Pearse, 1942} \\
\hline \multicolumn{10}{|c|}{ Family Tylencholaimidae Filipjev, 1934} \\
\hline Tylencholaimus de Man, $1876^{*}$ & $\mathrm{~F}_{4}$ & 3.6 & 2.9 & 0.4 & 12.6 & 0.3 & 9.3 & 11.3 & 21.6 \\
\hline \multicolumn{10}{|c|}{ Family Dorylaimidae de Man, 1876} \\
\hline Mesodorylaimus Andrássy, 1959 & $\mathrm{Om}_{5}$ & 0 & \begin{tabular}{|l|}
0 \\
\end{tabular} & 0.2 & 0 & 0 & 0 & 0 & 0 \\
\hline Dorylaimidae sp. & $\mathrm{Om}_{5}$ & 0 & 0 & 0 & 0 & 0 & 0 & 0.1 & 0 \\
\hline \multicolumn{10}{|c|}{ Family Qudsianematidae Jairajpuri, 1963} \\
\hline Eudorylaimus Andrássy, 1959* & $\mathrm{Om}_{4}$ & 12.7 & 1.5 & 3.6 & 1.7 & 9.7 & 16.1 & 11.0 & 3.0 \\
\hline \multicolumn{10}{|c|}{ Order Mononchida Jairajpuri, 1969} \\
\hline \multicolumn{10}{|c|}{ Family Anatonchidae Jairajpuri, 1969} \\
\hline Iotonchus Cobb, 1916 & $\mathrm{Pr}_{4}$ & 0 & 0 & 0 & 0 & 1.3 & 1.2 & 0 & 0 \\
\hline & Famil & y Monon & chidae $\mathrm{Ch}$ & itwood, 1 & 937 & & & & \\
\hline Clarkus Jairajpuri, 1970 & $\operatorname{Pr}_{4}$ & 0 & 0 & 0 & 0 & 0.3 & 4.1 & 0 & 0 \\
\hline Prionchulus Cobb, 1916 & $\mathrm{Pr}_{4}$ & 1.2 & 0 & 0 & 0 & 11.4 & 0.4 & 0 & 0 \\
\hline & Order & Chroma & dorida Chi & twood, 19 & 933 & & & & \\
\hline & Family Achr & omadoric & dae Gerlac & h \& Riem & lann, 1973 & & & & \\
\hline Achromadora Cobb, 1913 & $\mathrm{~B}_{2}$ & 1.5 & 0.2 & 0 & 0 & 3.9 & 1.9 & 0.6 & 0 \\
\hline & Order & Desmodo & orida De C & oninck, 1 & 965 & & & & \\
\hline & Fami & ly Desmo & doridae $\mathrm{F}$ & ilipjev, 19 & & & & & \\
\hline Prodesmodora Micoletzky, 1923 & $\mathrm{~B}_{2}$ & 0 & 0 & 0.2 & 0 & 0 & 0.4 & 0 & 1.5 \\
\hline & Ord & er Monhy & sterida Fil & ipjev, 192 & & & & & \\
\hline & Famil & y Monhy & steridae D & e Man, 18 & & & & & \\
\hline Eumonhystera Andrássy, 1981 & $\mathrm{~B}_{2}$ & 0 & 0 & 0.2 & 0 & 0.3 & 0.4 & 5.4 & 1.1 \\
\hline Monhystrella Cobb, 1918 & $\mathrm{~B}_{2}$ & 0 & 0 & 1.5 & 1.4 & 0.8 & 0 & 2.5 & 0.4 \\
\hline & & der Plect & ida Malakl & hov, 1982 & & & & & \\
\hline & & amily Ple & ectidae Örl & ey, 1880 & & & & & \\
\hline Plectus Bastian, 1865* & $\mathrm{B}_{2}$ & 14.9 & 14.7 & 2.1 & 3.2 & 32.9 & 16.6 & 18.5 & 4.3 \\
\hline Ceratoplectus Andrassy, 1984 & $\mathrm{~B}_{2}$ & 0 & 0 & 0 & 0 & 0 & 0.4 & 0 & 0 \\
\hline Wilsonema Cobb 1913 & $\mathrm{~B}_{2}$ & 0.5 & 0 & 0 & 0.2 & 0 & 0 & 1.1 & 0.4 \\
\hline & Family M & etateratoc & cephalidae & Eroshenk & ко, 1973 & & & & \\
\hline Metateratocephalus Eroshenko, 1973 & $\mathrm{~B}_{3}$ & 0 & 0 & 0 & 0 & 2.4 & 3.5 & 2.1 & 0 \\
\hline
\end{tabular}




\begin{tabular}{|c|c|c|c|c|c|c|c|c|c|}
\hline \multirow{3}{*}{ Taxa } & \multirow{3}{*}{$\begin{array}{l}\text { Functional } \\
\text { guilds of } \\
\text { nematodes }\end{array}$} & \multicolumn{4}{|c|}{ Kostomuksha State Nature Reserve } & \multicolumn{4}{|c|}{ Eastern Finland (Kuhmo and Elimyussalo) } \\
\hline & & \multicolumn{2}{|c|}{$\begin{array}{c}\text { Site } 1 \\
\text { (pine forest) }\end{array}$} & \multicolumn{2}{|c|}{$\begin{array}{c}\text { Site } 2 \\
\text { (spruce forest) }\end{array}$} & \multicolumn{2}{|c|}{$\begin{array}{c}\text { Site } 3 \\
\text { (pine forest) }\end{array}$} & \multicolumn{2}{|c|}{$\begin{array}{c}\text { Site } 4 \\
\text { (spruce forest) }\end{array}$} \\
\hline & & $0-5 \mathrm{~cm}$ & $5-10 \mathrm{~cm}$ & $0-5 \mathrm{~cm}$ & $5-10 \mathrm{~cm}$ & $0-5 \mathrm{~cm}$ & $5-10 \mathrm{~cm}$ & $0-5 \mathrm{~cm}$ & $5-10 \mathrm{~cm}$ \\
\hline \multicolumn{10}{|c|}{ Family Teratocephalidae Andrássy, 1958} \\
\hline Teratocephalus de Man 1876* & $\mathrm{B}_{3}$ & 0 & 0.2 & 0.2 & 0.4 & 0.3 & 2.5 & 3.0 & 0.2 \\
\hline \multicolumn{10}{|c|}{ Order Rhabditida Chitwood, 1933} \\
\hline \multicolumn{10}{|c|}{ Family Panagrolaimidae Thorne, 1937} \\
\hline Panagrolaimus Fuchs, 1930 & $\mathrm{~B}_{1}$ & 0 & 0 & 0.4 & 0.5 & 0.1 & 0 & 0 & 0.2 \\
\hline \multicolumn{10}{|c|}{ Family Cephalobidae Filipjev, 1931} \\
\hline Acrobeloides Cobb, 1924* & $\mathrm{B}_{2}$ & 13.8 & 42.1 & 6.3 & 7.9 & 5.0 & 12.1 & 13.0 & 20.0 \\
\hline Cephalobus Bastian, 1865 & $\mathrm{~B}_{2}$ & 0 & 0 & 0 & 0 & 1.9 & 0 & 2.2 & 5.8 \\
\hline Cervidellus Thorne 1937 & $\mathrm{~B}_{2}$ & 0 & 0 & 0.2 & 0 & 0 & 0 & 0 & 0 \\
\hline Chiloplacus Thorne 1937* & $\mathrm{B}_{2}$ & 2.5 & 1.0 & 1.3 & 22.7 & 1.4 & 7.7 & 3.0 & 5.4 \\
\hline Heterocephalobus Brzeski 1960 & $\mathrm{~B}_{2}$ & \begin{tabular}{|l|l|l|l|l|l|}
0 & \\
\end{tabular} & 0 & 0 & 0 & 0.6 & 0.2 & 0 & 0 \\
\hline \multicolumn{10}{|c|}{ Family Rhabditidae Örley, 1880} \\
\hline Rhabditis Dujardin 1845 & $\mathrm{~B}_{1}$ & 0 & 0 & 1.4 & 0.7 & 1.4 & 4.1 & 1.4 & 0.4 \\
\hline \multicolumn{10}{|c|}{ Family Steinernematidae Filipjev, 1934} \\
\hline Steinernema Travassos, 1927 & IP & 0 & 0 & 0 & 0 & 0 & 0 & 0.2 & 0 \\
\hline \multicolumn{10}{|c|}{ Family Tylenchidae Örley, 1880} \\
\hline Filenchus Andrássy, 1954 & $\mathrm{Asp}_{2}$ & 0 & 0 & 1.1 & 13.5 & 6.8 & 3.0 & 0 & 0 \\
\hline Malenchus Andrássy, 1968* & $\mathrm{Asp}_{2}$ & 32.1 & 10.4 & 28.6 & 11.5 & 2.0 & 2.0 & 0 & 1.5 \\
\hline Aglenchus Andrássy, 1954 & $\mathrm{Asp}_{2}$ & 0 & 0 & 0 & 0 & 0.3 & 0 & 0.2 & 0.5 \\
\hline Coslenchus Siddiqi, 1978* & $\mathrm{Asp}_{2}$ & 0.7 & 0 & 3.2 & 2.1 & 0 & 0.5 & 0.2 & 1.3 \\
\hline Lelenchus Andrássy, 1954* & $\mathrm{Asp}_{2}$ & 2.1 & 1.0 & 1.1 & 0.7 & 4.0 & 6.6 & 4.6 & 8.2 \\
\hline Tylenchus Bastian, 1865 & $\mathrm{Asp}_{2}$ & 0 & 0 & 0 & 0 & 2.4 & 0 & 0.1 & 0 \\
\hline Ecphyadophora de Man, 1921 & $\mathrm{Pp}_{2}$ & 0 & 0 & 0 & 0 & 0 & 0 & 0 & 2.6 \\
\hline \multicolumn{10}{|c|}{ Family Anguinidae Nicoll, 1935} \\
\hline Ditylenchus Filipjev, 1936* & $\mathrm{F}_{2}$ & \begin{tabular}{|l|l|l|l|l|l}
0 & \\
\end{tabular} & 0.2 & 8.3 & 7.1 & 3.2 & 0.4 & 0 & 0.7 \\
\hline \multicolumn{10}{|c|}{ Family Belonolaimidae Whitehead, 1959} \\
\hline Geocenamus Thorne \& Malek, 1968 & $\mathrm{Pp}_{3}$ & 0 & 0.5 & 0 & 0 & 0 & 0 & 0 & 0 \\
\hline \multicolumn{10}{|c|}{ Family Tylenchulidae Skarbilovich, 1947} \\
\hline Paratylenchus Micoletzky 1922 & $\mathrm{Pp}_{2}$ & \begin{tabular}{|l|l|l|}
0 & \\
\end{tabular} & 1.2 & 0 & 0 & 0 & 0 & 0 & 0 \\
\hline \multicolumn{10}{|c|}{ Family Heteroderidae Filipjev \& Schuurmans Stekhoven, 1941} \\
\hline Heterodera Schmidt, 1871 & $\mathrm{Pp}_{3}$ & 0 & 0 & 0 & 0 & 0 & 0 & 0 & 0.2 \\
\hline \multicolumn{10}{|c|}{ Family Hoplolaimidae Filipjev, 1934} \\
\hline Helicotylenchus Steiner, 1945 & $\mathrm{Pp}_{3}$ & \begin{tabular}{|l|l|l|}
0 & \\
\end{tabular} & 0 & 0 & 0 & 0 & 0.4 & 0 & 0 \\
\hline \multicolumn{10}{|c|}{ Family Criconematidae Taylor 1936} \\
\hline Criconema Hofmänner \& Menzel, 1914 & $\mathrm{Pp}_{3}$ & 0 & 0 & 0.5 & 0.5 & 0 & 0 & 0 & 0 \\
\hline \multicolumn{10}{|c|}{ Family Aphelenchoididae Skarbilovich, 1947} \\
\hline Aphelenchoides Fischer, 1894* & $\mathrm{F}_{2}$ & \begin{tabular}{|l|}
13.7 \\
\end{tabular} & 22.4 & 37.0 & 13.0 & 6.5 & 2.3 & 18.0 & 17.9 \\
\hline & Family & Diplogas & stridae Mi & coletzky, & 1922 & & & & \\
\hline Diplogastridae sp. & $\mathrm{B}_{1}$ & 0 & 0 & 0.4 & 0 & 0 & 0 & 0 & 0 \\
\hline Total number of taxa: 45 & 15 & 13 & 15 & 23 & 18 & 25 & 27 & 21 & 24 \\
\hline & 10 & & 18 & 2 & & & 3 & & 29 \\
\hline
\end{tabular}

Note: * - nematode taxa observed in all sampling sites. List of nematode taxa was composed according to De Ley \& Blaxter (2004) and Abebe et al. (2006). Functional guilds according to Ferris et al. (2001) combine trophic groups (Yeates et al., 1993a) and c-p values of nematodes (1-5 as subscripts) (Bongers, 1990). Trophic groups: B - bacterial feeders, F - fungal feeders, Om - omnivores, $\mathrm{Pr}$ - predators, $\mathrm{Pp}$ - plant parasites, Asp - nematodes associated with plants; IP - dispersal/infective stages of insect parasites. 
Table 3. Characteristics of nematode communities in the soil of four coniferous forests in the Finnish-Russian Friendship Nature Reserve

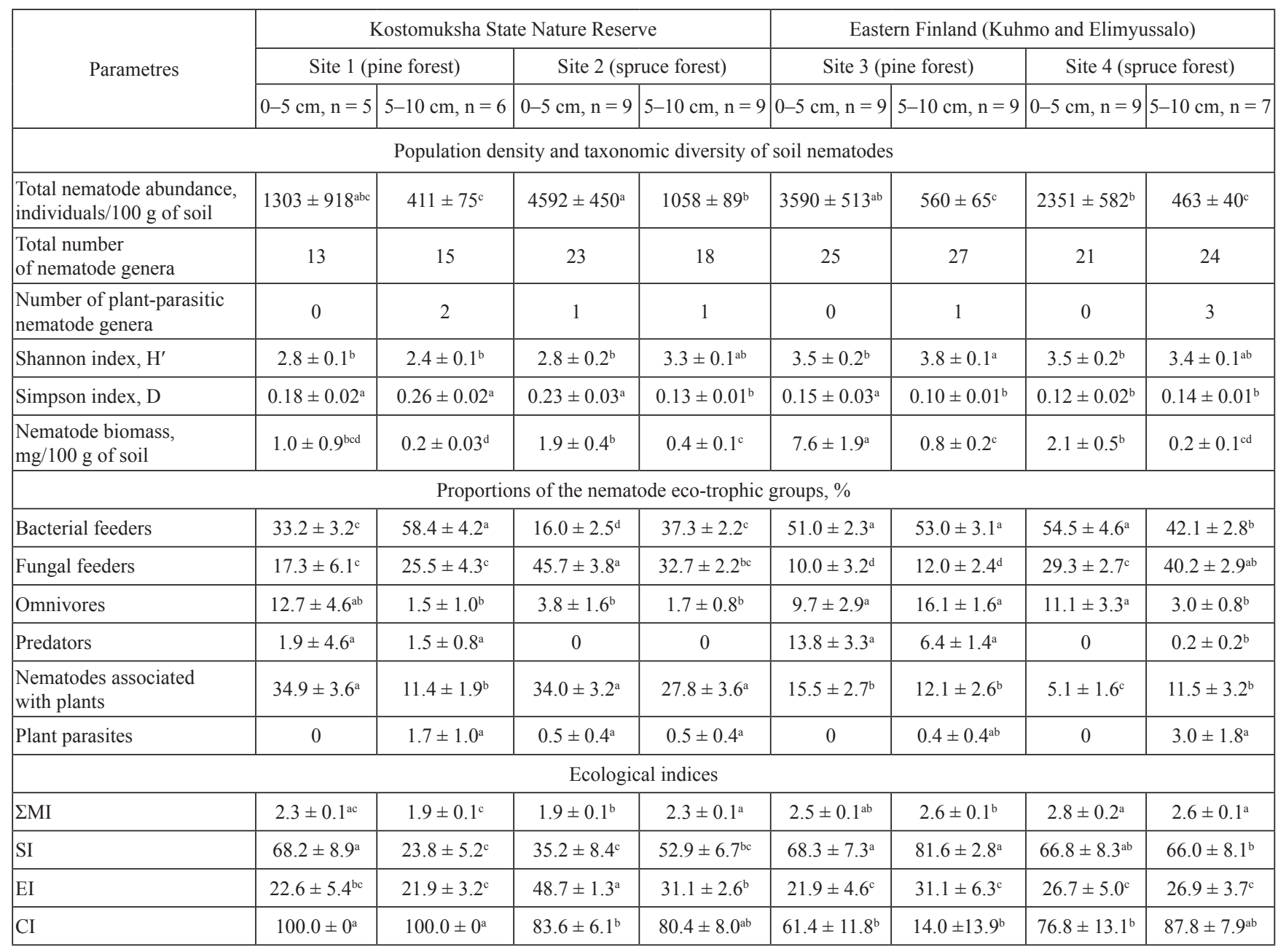

Note: $\mathrm{n}$ - number of replicates; $\mathrm{H}^{\prime}$ - Shannon index, D - Simpson index, $\Sigma \mathrm{MI}$ - maturity index of nematode communities, SI - structure index of soil food web; EI - enrichment index of soil food web, CI - channel index of dominant pathway of organic matter decomposition in soil ecosystem. Data are presented as mean \pm standard error of the mean. The Mann-Whitney U-test is used. Values with different letters in lines are significant ( $\mathrm{p}<0.05)$.

An analysis of functional guilds made it possible to reveal the patterns of changes in the composition of taxa with various ecological preferences within eco-trophic groups. Thus, we demonstrated that the highest taxonomic diversity was noted for $\mathrm{B}_{2}\left(5-10\right.$ taxa) and for $\mathrm{Asp}_{2}$ (3-6 taxa) (Table 2). Bacterial feeders belonging to functional guild $\mathrm{B}_{1}$ are typical colonisers with c-p value 1 , and r-strategists according to Bongers (1990). They were not found in the pine forests of the NR Kostomuksha. Predators from functional guilds $\operatorname{Pr}_{3}, \operatorname{Pr}_{4}$ (i.e. c-p values $3,4)$ were more confined to pine forests than to spruce forests, regardless of the study area. On the contrary, omnivores from functional guild $\mathrm{Om}_{5}$ tended to spruce forests. The diversity of other functional guilds was represented more evenly. For example, fungal feeders $\mathrm{F}_{2}$ and $\mathrm{F}_{4}$, omnivores $\mathrm{Om}_{4}$, plant parasites $\mathrm{Pp}_{3}$ were found in all biocenoses and with an equal number of taxa. The highest number of functional guilds (13) was found in the spruce forest in Finland. The presence of representatives from the family Trichodoridae (K-strategists) belonging to functional guild $\mathrm{Pp}_{4}$ in the fauna is a feature of this habitat type (Table 2).

\section{Population density and biomass}

The population density of soil nematodes varied significantly between the sampling sites; the highest abundance was found in the spruce forest (Site 2), and the lowest number in the pine forest (Site 1) of the NR Kostomuksha (Table 3). For biomass, the highest value was found in the pine forest in the Finnish territory, while for the other three biocenoses, close values of the biomasses were established. The tendency for a decrease in nematode numbers and biomass from the forest litter to the mineral horizon of the soil is common for all sites (Table 3). 


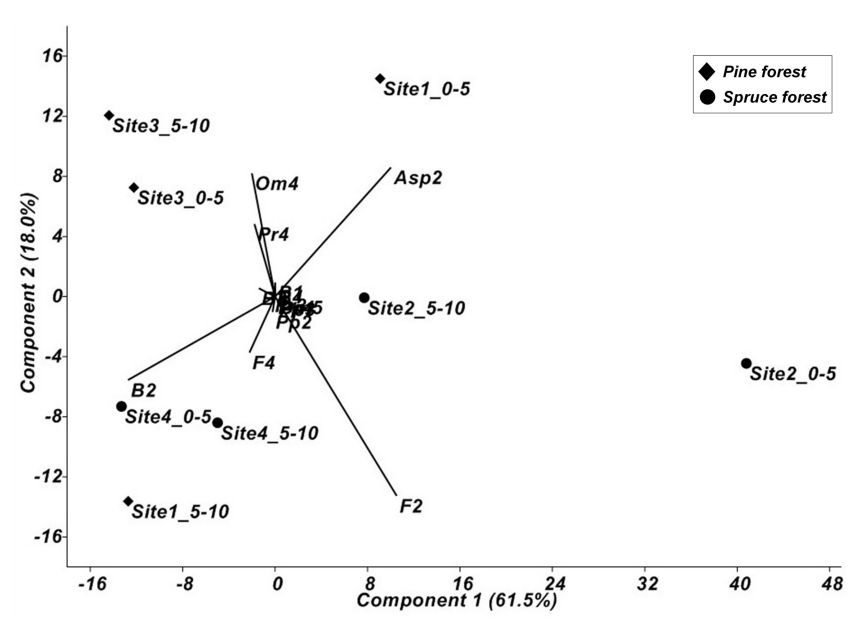

Fig. 2. Principal component analysis ordination diagram of the relative abundance of nematode functional guilds in four coniferous forests in the Kostomuksha State Nature Reserve and Protected Areas in adjacent area of Finland. Designations: sample sites and functional guilds of nematodes are abbreviated in Table $2 ;\langle 0-5 »$ and $\langle 5-10 »$ indicate litter samples and mineral soils, respectively.

\section{Eco-trophic structure}

An analysis of the eco-trophic structure of nematode communities showed that bacterial-, fungal feeders and nematodes associated with plants predominated in the soil of coniferous forests, and they were also distinguished by a high abundance. The smallest proportion in the structure of communities was observed in $\mathrm{Pp}$ nematodes. In some biocenoses, plant parasites (all sites excepting Site 2) and/or predators (Site 2 and 4) were absent and the nematode community structure was incomplete. In addition, differences between biocenoses were revealed: the relative abundance of fungal-feeding nematodes in the soil of spruce forests was higher than that in pine forests, regardless of the studied area. A regional feature that was noted was a greater percentage of nematodes associated with plants in the community of coniferous forests of the NR Kostomuksha, as compared with forests in Eastern Finland. The nematode community of the pine forest in Kuhmo had peculiarities and markedly differed from ones of the other forests by a high abundance of omnivorous and predaceous nematodes (Table 3 ).

Taking into account the differences existing between eco-trophic groupings of nematode communities among coniferous forests, a principal component analysis (PCA) was carried out. The PCA is based on the relative abundance of functional guilds of nematodes in the study area. The PCA made it possible to establish taxa that quantitatively prevailed in the fauna of the four sites and to determine the specificities of soil nematode communities (Fig. 2). The first axis explained more than $61 \%$ of the total variance. It was associated with the contribution of $\mathrm{B}_{2}, \mathrm{~F}_{2}$, and $\mathrm{Asp}_{2}$ to the fauna composition (Fig. 2). A smaller part of the variation (about $18 \%$ along the second axis) was caused by the proportion of nematodes belonging to functional guilds $\mathrm{Asp}_{2}, \mathrm{Om}_{4}$ and $\mathrm{F}_{2}$ in the communities. Most sample sites were characterised by a high abundance of $B_{2}$, with the exception of Site 2_0-5 (litter of the spruce forest in the NR Kostomuksha) where $\mathrm{F}_{2}$ predominated. Moreover, samples from spruce forests (Site 2 (mineral layer) and Site 4) were also characterised by a high contribution of nematodes from functional guild $\mathrm{F}_{2}$ to the fauna. The close location of pine forests (Site 1 and Site 3) in Fig. 2 was occurred also due to the more numerous representatives of functional guild $\mathrm{Om}_{4}$. Samples from NR Kostomuksha, with the exception of Site 1 (mineral layer), were separated due to the high abundance of $\mathrm{Asp}_{2}$ nematodes (Fig. 2).

Differences in relative abundance of nematode taxa between soil horizons in the studied biocenoses were observed. In the conifer forest litter, a high level of dominance was noted for the bacterial feeder Plectus (with a higher abundance in Finland), the plant-associated Malenchus (with a high abundance in the NR Kostomuksha) and the fungal feeder Aphelenchoides, which showed a tendency to be more abundant in spruce forests than in pine forests. In the mineral soil layer of the coniferous forests of the NR Kostomuksha, bacterial feeders from the Cephalobidae family (Acrobeloides in the pine forest, Chiloplacus in the spruce forest) predominated. At the same time, other dominant taxa were revealed in the forests of Eastern Finland, including nematodes of the genera Plectus and Eudorylaimus with similar values of relative abundance in the pine forest, and Tylencholaimus and Acrobeloides in the spruce forest (Table 2). Thus, among the dominant nematode genera in coniferous forests of Finland, there were taxa with high values on the Bongers c-p scale, considered sensitive to environmental conditions and K-strategists (omnivore Eudorylaimus and fungal feeder Tylencholaimus with c-p 4). The rest of the dominant taxa described above were estimated with c-p 2. They are characterised by a wide ecological plasticity and form a core of the basal nematode community of any biocenosis. In 
addition, the nematode fauna of coniferous forests in Finland was characterised by markedly lower values of the Simpson index in comparison with the NR Kostomuksha (Table 3 ).

\section{Ecological indices}

A calculation of ecological indices showed that, regardless of the soil horizons, in coniferous forests of Finland, the SI index was higher than 50. This indicates that the nematode communities are mature and the soil ecosystems are undisturbed (Table 3). The smallest SI index values were noted in the coniferous forests of the NR Kostomuksha. This was associated with the absence or a low proportion of nematodes belonging to $\mathrm{K}$-strategists (omnivores, predators) in the community structure. This parameter testifies the simplification and instability of the food web and that soil ecosystems are subjected to adverse environmental (climatic or anthropogenic) factors. The maturity index of nematode communities $(\Sigma \mathrm{MI})$ had minimal values in the mineral layer of Site 1_5-10 (pine forest) and in the litter of Site 2_0-5 (spruce forest) NR Kostomuksha, while in the forests of Eastern Finland, the $\Sigma$ MI values were generally higher. Thus, the $\Sigma \mathrm{MI}$ and SI indices, being indicators of the environment disturbance degree, varied in the biocenoses in a similar way.

On majority of the sites, the EI index had low values, i.e. the soils were depleted in available organic matter with one exception (Site 2 0-5 in spruce forest of the NR Kostomuksha). On this site, higher EI values were observed. This demonstrated the moderate level of soil enrichment with available organic matter. The CI index of the predominant pathway of organic matter decomposition in the soil had high values. This indicated the active participation of soil fungi in the organic matter decomposition. However, there was one exception (mineral layer of Site 3 ) with a low CI value that showed a bacterial pathway in the destruction of organic matter in the soil.

\section{Discussion}

The study of taxonomic diversity, abundance and other characteristics of soil nematodes in coniferous forests of the Finnish-Russian Friendship Nature Reserve made it possible to obtain new data on the nematode fauna and to reveal interesting features of their communities. In this study, the highest taxonomic diver- sity among coniferous forests was found in pine forests in Finland. However, it was lower than that in Sweden (Sohlenius \& Boström, 2001), but higher than for pine forests in the Republic of Karelia (Matveeva \& Sushchuk, 2016). In the pine forest of the NR Kostomuksha, the low taxonomic diversity reflected the unfavourable habitat conditions for pedobionts. It is known, that the tundra of the Subarctic zone is characterised by a low diversity of soil nematodes due to the extreme habitat conditions (Sushchuk et al., 2018). On the other hand, this parameter may also reflect the impact of pollution or other anthropogenic factors (Georgieva et al., 2002; Laidinen et al., 2013).

An analysis of the soil nematode abundance and biomass showed established differences in these parameters between the forest litter (maximum values) and the underlying mineral horizon (with significantly lower values), despite the high variability in biocenoses. A similar pattern, presumably associated with a higher carbon and nitrogen contents in the forest litter, was also demonstrated in other nematological studies of coniferous forests (Ruess, 1995; Sohlenius \& Boström, 2001; Gruzdeva et al., 2006). In an earlier nematological research of coniferous forests in the Republic of Karelia $\left(61-66^{\circ} \mathrm{N}\right)$, Matveeva $\&$ Sushchuk (2016) showed that the number of nematodes in soils of spruce forests significantly exceeded that in pine forests. However, for the studied northern taiga forests, a similar trend was not identified. A larger biomass was found in the forest litter of the pine forest in Finland, which is explained by the high number of largesized nematodes belonging to the predators and omnivores on Site 3. In the rocky pine forest, the high abundance of these groups may be the consequence of the scarce food resources available to soil nematodes. In poor northern soils, nematodes with a wide range of nutrition preferences gained advantage, and to a lower extent depended on the content of available organic matter in the soil (Gruzdeva et al., 2005; Kalinkina et al., 2019).

By analysing the eco-trophic structure of nematode communities in coniferous forests, a predominance of bacterial and fungal feeders, and nematodes associated with plants was revealed with a low abundance or absence of predaceous and plant-parasitic nematodes. This pattern of nematode community structure is typical for both pine and spruce forests in the Republic of Karelia (Matveeva \& Sushchuk, 2016), and 
other regions (Magnusson, 1983; Ruess, 1995; Háněl, 2001; Sohlenius \& Boström, 2001).

According to the literature data, the dominant taxa of pine forests in Sweden were $A c$ robeloides (B), Aphelenchoides (F), Plectus (B) and Filenchus (Asp) (Sohlenius \& Boström, 2001), in Germany Filenchus (Asp), Plectus (B), Eudorylaimus (Om), Aphelenchoides (F), and Acrobeloides (B) (Háněl, 2001), in pine forests of Finland Plectus (B), Cephalobidae (B), Aphelenchoides (F), and Tylenchus (Asp) (Räty \& Huhta, 2003). For spruce forests in Germany, similar results were demonstrated. So, bacterial feeders of Plectus, Wilsonema, Acrobeloides, Teratocephalus, Metateratocephalus, as well as Filenchus (Asp) and Aphelenchoides (F) prevailed in the soil (Ruess, 1995). In the present study of the border areas of the Republic of Karelia and Eastern Finland, a high dominance level was noted for nematodes of the genera Plectus (B), Malenchus (Asp), and Aphelenchoides (F) in the forest litter, as well as for Cephalobidae (B) (Acrobeloides, Chiloplacus), Plectus (B) and Tylencholaimus (F) in the mineral soil horizon. Thus, the nematode fauna composition of coniferous forests was comparable with the results obtained elsewhere in Europe. Results on the vertical distribution of nematodes in the soil are also consistent with the data obtained for pine forests in Sweden (Sohlenius \& Boström, 2001). So, Plectus (B) and Aphelenchoides (F) have the highest abundance in the forest litter, and nematodes of the genus Acrobeloides (B) prevailed in mineral soil layer. A tendency towards a higher abundance of Acrobeloides in deeper soil horizons was also noted in spruce forests (Ruess, 1995). The majority of the dominant taxa had a higher abundance (in absolute values) in the forest litter of surveyed biocenoses due to a sharp decrease in the total nematode numbers in the underlying soil layer. However, data on the relative abundance showed that Plectus and Eudorylaimus tended to be more abundant in the forest litter. Acrobeloides (in all biotopes), Chiloplacus and Tylencholaimus (in most biotopes) were confined to the mineral soil, while Malenchus and Aphelenchoides did not show any clear patterns.

It is known that coniferous forests are usually characterised by high CI index values, indicating a considerable activity of soil fungi, the main food source of fungal feeding nematodes in organic matter decomposition (Matveeva \& Su- shchuk, 2016). In forest soils, organic matter is mainly represented by hard-to-decompose plant residues accumulated in the litter and soil fungi play a key role in their biotransformation (Zvyagintsev et al., 2005). The results obtained in the forests of the NR Kostomuksha are consistent with the published data. So, in these biotopes, the CI index had high values (80-100). However, in the mineral horizon of the pine forest soil in Kuhmo (Site 3_5-10), a low index value was revealed (14), indicating a bacterial pathway of organic matter decomposition. A number of studies also demonstrated a high variation in this parameter in coniferous forests (Háněl, 2001). It can be assumed that the presence of a bacterial pathway of organic matter decomposition is associated with better texture, fertility and lower acidity ( $\mathrm{pH}=4.8)$ of the soil on Site 3 .

In NR Kostomuksha, low values of the SI, $\Sigma \mathrm{MI}$ and EI indices indicated the simplification and instability of the food web, depletion in available organic matter, and that the soil ecosystem is subjected to local-scope adverse environmental factors (climatic or anthropogenic). The obtained data are consistent with the «basal food web» concept of Ferris et al. (2001) to designate a primitive web represented by nematodes with wide ecological plasticity with c-p 2 , mainly bacterial and fungal feeders. The authors attribute the simplicity of the food web to stress factors, including resource constraints or extreme environmental conditions. The results obtained in this study are apparently associated with both the features of the northern taiga ecosystems and with the negative consequences of the activities of the Kostomuksha Mining and Processing Plant.

\section{Conclusions}

The research of the fauna and community structure of soil nematodes in pine and spruce forests in the Finnish-Russian Friendship Nature Reserve provided new data on diversity and distribution of nematodes. In the surveyed forests, the soil nematode fauna was represented by 45 nematode genera belonging to 29 families. The compiled list of nematode taxa made it possible to expand the understanding of the soil nematode diversity in north-taiga forests. Additionally, it has relevance for the development of monitoring biodiversity and the state of the environment under conditions of global climatic changes and anthropogenic impacts. 
This study identified some aspects of the vertical nematode distribution and established a relationship of nematological parameters with the biocenose types and local features of the sites. Independently of surveyed site and biocenosis type, a common trend was a high abundance and biomass of nematodes in the forest litter and a considerable decrease in these parameters in the mineral soil layer. However, the nematode Acrobeloides exhibited a tendency to have a relatively higher abundance in the mineral layer as compared with forest litter. In pine forests of both Russian and Finnish parts of the Friendship Nature Reserve, soil nematode communities were noted with a higher diversity and relative abundance of predators, while in spruce forests they had a higher abundance of fungal feeders, particularly Aphelenchoides.

The regional features of the nematode fauna in the Kostomuksha State Nature Reserve concern its low diversity and high dominance levels of taxa, low maturity index ( $\Sigma \mathrm{MI})$ of the nematode communities and low structure index (SI) of soil food web. This may be caused as a result of anthropogenic impact on the studied sites (close location of soil sampling sites to the road, and negative consequences of activities of the Kostomuksha Mining and Processing Plant) or other local adverse environmental factors. To clarify the situation, it is necessary to monitor the soil nematodes in the coniferous forests of the Kostomuksha State Nature Reserve.

On the other hand, coniferous forests in the Finnish territory showed a higher diversity of the nematode fauna, high Shannon index values and a lower dominance level of taxa (a more evenly structured fauna). The Finnish forests harboured 16 specific taxa not encountered in the Russian territory. They include plant parasites of the family Trichodoridae, which are rare in Northwest Russia, and the group of dominant taxa of K-strategy nematodes sensitive to environmental conditions. Thus, it can be concluded that the conditions of the Finnish territory are more favourable for soil nematodes. The ecological indices explored in the study (SI, EI) confirmed that Finnish coniferous forests are stable habitats with complex, multicomponent soil food webs and undisturbed soil ecosystems.

\section{Acknowledgments}

The research was financed by the Federal budget project (№0218-2019-0075). We express our gratitude to officers of Research Station of the Friendship Park in Kuhmo and Kostomuksha State Nature Reserve for technical support and assistance in the field.

\section{References}

Abebe E., Traunspurger W., Andrássy I. 2006. Freshwater nematodes: ecology and taxonomy. Wallingford: CABI Publishing. 752 p.

van Bezooijen J. 2006. Methods and techniques for nematology. Wageningen: Wageningen University Press. $112 \mathrm{p}$.

Bongers T. 1990. The maturity index: an ecological measure of environmental disturbance based on nematode species composition. Oecologia 83(1): 14-19. DOI: 10.1007/BF00324627

De Ley P., Blaxter M. 2004. A new system for Nematoda: combining morphological characters with molecular trees, and translating clades into ranks and taxa. In: R. Cook, D.J. Hunt (Eds.): Nematology Monographs and Perspectives. Vol. 2. Leiden: E.J. Brill. P. 633-653.

Dighton J., Helmisaari H.S., Maghirang M., Smith S., Malcolm K., Johnson W., Quast L., Lallier B., Gray D., Setälä H., Starr M., Luiro J., Kukkola M. 2012. Impacts of forest post thinning residues on soil chemistry, fauna and roots: Implications of residue removal in Finland. Applied Soil Ecology 60: 16-22. DOI: 10.1016/j.apsoil.2012.02.023

Fedorets N.G., Bakhmet O.N., Solodovnikov A.N. 2014. The soils and soil cover of the Russian-Finnish park «Friendship». Transactions of Karelian Research Centre of Russian Academy of Science 6: 24-38. [In Russian]

Ferris H., Bongers T., de Goede R.G.M. 2001. A framework for soil food web diagnostics: extension of the nematode faunal analysis concept. Applied Soil Ecology 18(1): 13-29. DOI: 10.1016/S09291393(01)00152-4

Georgieva S.S., McGrath S.P., Hooper D.J., Chambers B.S. 2002. Nematode communities under stress: the long-term effects of heavy metals in soil treated with sewage sludge. Applied Soil Ecology 20(1): 27-42. DOI: 10.1016/S0929-1393(02)00005-7

Gruzdeva L.I., Sushchuk A.A. 2009. Impact of industrial pollution on soil nematode communities in the Kostomuksha region. In: N.V. Vasilevskaya (Ed.): Conservation of biological diversity of terrestrial and marine ecosystems at high latitudes. Murmansk: Murmansk State Pedagogical University. P. 54-57. [In Russian]

Gruzdeva L.I., Kovalenko T.E., Matveeva E.M. 2005. Nematode fauna of meadow cenoses in the islands of the White Sea, Lakes Onego and Ladoga. Biogeography of Karelia. Proceedings of KarRC RAS. Series «Biology» 7: 39-47. [In Russian]

Gruzdeva L.I., Matveeva E.M., Kovalenko T.E. 2006. Soil nematode fauna of different forest types in Reserve 
«Kivach». Transactions of Karelian Research Centre of Russian Academy of Science 10: 14-21. [In Russian]

Hagner M., Mikola J., Saloniemi I., Saikkonen K., Helander M. 2019. Effects of a glyphosate-based herbicide on soil animal trophic groups and associated ecosystem functioning in a northern agricultural field. Scientific Reports 9(1): 8540. DOI: 10.1038/ s41598-019-44988-5

Hammer Ø., Harper D.A.T., Ryan P.D. 2001. Past: paleontological statistics software package for education and data analysis. Palaeontologia Electronica 4(1): 1-9.

Háněl L. 2001. Succession of soil nematodes in pine forests on coal-mining sands near Cottbus, Germany. Applied Soil Ecology 16(1): 23-34. DOI: 10.1016/ S0929-1393(00)00101-3

Huhta V., Koskenniemi A. 1975. Numbers, biomass and community respiration of soil invertebrates in spruce forests at two latitudes in Finland. Annales Zoologici Fennici 12(2): 164-182.

Huhta V., Karppinen E., Nurminen M., Valpas A. 1967. Effect of silvicultural practices upon arthropos, annelid and nematode populations in coniferous forest soil. Annales Zoologici Fennici 4(2): 87-145.

Huhta V., Hyvönen R., Kaasalainen P., Koskenniemi A., Muona J., Mäkelä I., Sulander M., Vilkamaa P. 1986. Soil fauna of Finnish coniferous forests. Annales Zoologici Fennici 23(4): 345-360.

Huhta V., Räty M., Ahlroth P., Hänninen S.M., Mattila J., Penttinen R., Rintala T. 2005. Soil fauna of deciduous forests as compared with spruce forests in central Finland. Memoranda Societatis pro Fauna et Flora Fennica 81: 52-70.

Kalinkina D.S., Sushchuk A.A., Matveeva E.M., Zenkova I.V. 2019. Communities of soil nematodes in the subcrown areas of trees introduced on the territory of the Polar-Alpine Botanical Garden. Contemporary Problems of Ecology 12(1): 59-70. DOI: 10.1134/ S1995425519010074

Laidinen G.F., Gruzdeva L.I., Titov A.F., Kaznina N.M., Batova Y.V., Sushchuk A.A. 2013. The state of herbaceous vegetation and nematode communities under industrial pollution. Transactions of Karelian Research Centre of Russian Academy of Science 6: 17-26. [In Russian]

Magnusson M.L. 1982. Nematodes in some coniferous forests in Finland. Seloste: Nematodien esiintymisestä suomen havumetsissä. Communicationes Instituti Forestalis Fenniae 103: 1-12.

Magnusson C. 1983. Abundance and trophic structure of pine forest nematodes in relation to soil layers and ground cover. Holarctic Ecology 6(2): 175-182. DOI: $10.1111 /$ j.1600-0587.1983.tb01079.x

Matveeva E.M., Sushchuk A.A. 2016. Features of soil nematode communities in various types of natural biocenoses: effectiveness of assessment parameters. Biology Bulletin 43(5): 474-482. DOI: 10.1134/ S1062359016040099

Matveeva E.M., Gruzdeva L.I., Kovalenko T.E., Sushchuk A.A. 2008. Soil nematodes as biological indicators of technogenic soil pollution in northern taiga ecosystems. Transactions of Karelian Research Centre of Russian Academy of Science 14: 63-75. [In Russian]

Odum E. 1975. Fundamentals of Ecology. Moscow: Mir. 740 p. [In Russian]

Räty M., Huhta V. 2003. Nematode communities of anthropogenous birch stands in central Finland. Nematology 5(4): 629-639. DOI: 10.1163/156854103322683346

Ruess L. 1995. Nematode fauna in spruce forest soils: A qualitative/quantitative comparison. Nematologica 41: 106-124.

Sieriebriennikov B., Ferris H., de Goede R.G.M. 2014. NINJA: An automated calculation system for nematode-based biological monitoring. European Journal of Soil Biology 61: 90-93. DOI: 10.1016/j.ejsobi.2014.02.004

Sohlenius B., Boström S. 2001. Annual and long-term fluctuations of the nematode fauna in a Swedish Scots pine forest soil. Pedobiologia 45(5): 408-429. DOI: 10.1078/0031-4056-00096

Stark S., Wardle D.A., Ohtonen R., Helle T., Yeates G.W. 2000. The effect of reindeer grazing on decomposition, mineralization and soil biota in a dry oligotrophic Scots pine forest. Oikos 90(2): 301-310. DOI: 10.1034/j.1600-0706.2000.900210.x

Stark S., Kytöviita M.M., Männistö M.K., Neumann A.B. 2008. Soil microbial and microfaunal communities and organic matter quality in reindeer winter and summer ranges in Finnish subarctic mountain birch forests. Applied Soil Ecology 40(3): 456-464. DOI: 10.1016/j.apsoil.2008.06.009

Sushchuk A.A., Matveeva E.M., Kalinkina D.S., Krivorot I.V. 2018. Communities of soil nematodes in tundra and taiga ecosystems (on an example of the NorthWest of Russia). In: A.V. Uvarov (Ed.): Problems of Soil Zoology. Moscow: KMK Scientific Press Ltd. P. 196-197. [In Russian]

Yeates G.W., Bongers T., de Goede R.G.M., Freckman D.W., Georgieva S.S. 1993a. Feeding habits in soil nematode families and genera - An outline for soil ecologists. Journal of Nematology 25(3): 315-331.

Yeates G.W., Wardle D.A., Watson R.N. 1993b. Relationships between nematodes, soil microbial biomass and weed-management strategies in maize and asparagus cropping systems. Soil Biology and Biochemistry 25(7): 869-876. DOI: 10.1016/0038-0717(93)90089-T

Zvyagintsev D.G., Babieva I.P., Zenova G.M. 2005. Soil Biology. Moscow: Moscow State University. 445 p. [In Russian] 


\title{
ПОЧВЕННЫЕ НЕМАТОДЫ ХВОЙНЫХ ЛЕСОВ РОССИЙСКО-ФИНЛЯНДСКОГО ЗАПОВЕДНИКА «ДРУЖБА»
}

\author{
А. А. Сущук* ${ }^{*}$, Е. М. Матвеева $\mathbb{D}$ \\ Институт биологии Карельского научного иееттра РАН, Россия \\ *e-mail:anna_sushchuk@mail.ru
}

В статье рассмотрены сообщества почвенных нематод сосняков и ельников российско-финляндского заповедника «Дружба». Эта территория является примером типичных северотаежных лесов и объединяет государственный природный заповедник «Костомукшский» (Республика Карелия, Россия) и парк «Дружба», состоящий из пяти особо охраняемых природных территорий (ООПТ) на прилегающей территории Финляндии. С помощью общепринятых нематологических методов были изучены следующие параметры: таксономическое разнообразие, плотность популяций, биомасса, экологотрофическая структура сообществ нематод и эколого-популяционные индексы, характеризующие почвенную трофическую сеть. Фауна почвенных нематод исследованных хвойных лесов представлена 45 родами нематод, относящимися к 29 семействам, при наибольшем разнообразии бактериотрофов ( $42 \%$ от общего числа выявленных таксонов). Показано, что хвойные леса на территории Финляндии выделялись большим числом выявленных таксонов (29-33) и высокими значениями индекса Шеннона $\left(\mathrm{H}^{\prime}\right)$ (3.4-3.8) при их сопоставлении с таковыми в заповеднике «Костомукшский» (18-24 таксона и $\mathrm{H}^{\prime}=2.4-3.3$, соответственно). Для всех исследованных лесов выявлена общая тенденция снижения численности и биомассы нематод от лесной подстилки к минеральному слою почвы. Тренд был более выражен на финской территории. Методом главных компонент на основании относительного обилия функциональных групп нематод было показано, что леса Восточной Финляндии имели более однородную фауну нематод при сравнении почвенных горизонтов. Анализ эколого-трофической структуры сообществ нематод в почве хвойных лесов показал высокое обилие бактериотрофов, микотрофов и нематод, ассоциированных с растениями, при низком обилии или полном отсутствии фитопаразитов. Особенностью сообществ почвенных нематод сосняков (Pinus sylvestris) на всей территории заповедника «Дружба» являлось более высокое разнообразие и относительное обилие хищников, а ельников (Picea abies) - более высокое обилие микотрофов в сравнении с сосняками. В качестве региональных особенностей фауны нематод заповедника «Костомукшский» можно выделить ее низкое таксономическое разнообразие и высокий уровень доминирования таксонов (высокие значения индекса Симпсона), низкие значения индекса зрелости сообществ нематод ( $\Sigma \mathrm{MI})$ и индекса структурирования (SI), причиной которых может быть антропогенное воздействие или другие локально действующие неблагоприятные факторы среды. В сообществах нематод лесов на территории Финляндии выявлено более высокое таксономическое разнообразие фауны и меньший уровень доминирования таксонов (т.е. структура фауны более выровнена). В лесах финской территории найдены 16 специфичных таксонов, не встреченных на российской территории, и обнаружены паразиты растений из семейства Trichodoridae, редкие для северо-запада России. Кроме того, среди доминирующих таксонов присутствуют нематоды К-стратеги, чувствительные к условиям среды. Таким образом, можно предположить, что на финской территории складываются более благоприятные условия для обитания почвенных нематод. Рассмотренные эколого-популяционные индексы (SI, EI) подтверждают, что хвойные леса Финляндии представляют собой стабильные местообитания со сложными, многокомпонентными почвенными трофическими сетями и ненарушенными почвенными экосистемами. Напротив, леса заповедника «Костомукшский» характеризуются значениями индексов, свидетельствующими об упрощенной и нестабильной трофической сети, приуроченной к деградированным почвенным экосистемам, испытывающим воздействие неблагоприятных факторов среды.

Ключевые слова: ООПТ, плотность популяций, сообщество почвенных нематод, таксономическое разнообразие, эколого-популяционные индексы, эколого-трофическая структура 